Ковпік C. I.

доктор філологічних наук, професор КПІ ДВНЗ «Криворізький наиіональний університет»

\title{
УКРАЇНСЬКІ РІМЕЙКИ П'ЄС НІМЕЦЬКОГО ДРАМАТУРГА А. КОЦЕБУ
}

У статті з точки зору мікро- та макропоетики досліджено рімейкипереклади п'єси німецького драматурга Августо Коцебу «Втрчена дитина» українським драматургом В. Ковальським. Аналіз рімейка В. Ковальського показав, щчо автор не намагався особливо перевершити драматурга А. Кочебу в драматургічному мистецтві. Перекладач лише адаптував текст оригіналу, але не вносячи якихось суттевих змін і в техніку п'єси.

Ключові слова: рімейк, мікропоетика, макропоетика.

В статье исследованы микро- и маропоэтика ремейка-перевода пьесы Августо Кочебу «Потерянный ребёнок» украинцем В. Ковальским. Анализ ремейка В. Ковальского показал, что автор не попытался превзойти драматурга А. Коцебу в драматургическом мастерстве. Переводчик лишь адаптировал текст, не внеся каких-либо существенных изменений в технику пьесы.

Ключевые слова: ремейк, микропоэтика, макропоэтика.

The article is devoted to poetics of a remake-translator $V$. Kovalskiy. Analysis of the show-plays: playwright's utilization of concentration, composition and contrast.

Key words: remake, micropoetics, macropoetics.

Рімейк, за У. Еко, на відміну від рітейку пишеться майже одразу після появи першоджерела i тому дуже 3 ним пов'язаний. Тобто рімейк і тісно пов'язаний 3 першоджерелом, і в той же час має бути настільки оригінальним, що може і повинен конкурувати 3 першоджерелом. Загалом рімейк - це така (здійснена в рамках одного виду мистецтва) переробка недавно написаного й достатньо відомого твору, в якій подається «інноваційне повторення» i характерів, і сюжету, і загальної суспільної ситуації (причин, умов, мотивів діяльності персонажів і самого автора).

Навіть попереднє і досить побіжне знайомство зі здобутками драматургознавців Європи свідчить, що і до процесу рімейкування побутує переважно негативне ставлення, а саме поняття 
«рімейк» має також не зовсім позитивне смислове навантаження. I це пояснюється передусім тим, що найбільш поширеними переробками п’єс в Україні були пародії і такі «рімейкування», що їх важко назвати новими авторськими версіями, а скоріш примітивним плагіатом.

У літературознавстві близького зарубіжжя за останні десять років увага до способів рімейкування творів драматургії значно зросла, і свідченням цього є публікації таких авторів, як Г. Нефагіна, І. Банах, О. Домина, О. Таразевич, О. Самаріна та ін.

Як відомо, свого часу ще У. Еко в праці «Інновація і повторення» визначив такі основні принципи «творчого повторення»: ретейк, рімейк, інтертекстуальність. На думку цього вченого, ретейком є таке повторне зображення життєдіяльності відомих персонажів, про подальшу долю яких реципієнт дізнається з переробленого твору. Автор переробки завдяки надпотужній силі фантазії та за допомогою художнього домислу приносить ще більшу славу персонажам твору. Цей різновид повторення притаманний кінематографу, оскільки саме в цьому, синтетичному, виді мистецтва для домислювання $є$ найбільше можливостей, тобто в кіно ретейк має найбільший ефект.

I все-таки (як і будь-яке «повторне втілення») рімейк може бути і примітивним переказом, по-різному функціонально, формально та якісно довантаженим - аж настільки, що саме така «переробка» починає дійсно конкурувати $з$ першоджерелом. А це значить, що і сам процес рімейкування, і його наслідки та поняття про них вимушують нас говорити про той чи той рімейк по-різному: або як про самостійний і якоюсь мірою оригінальний художній твір, або як про таку «переробку», яка заслуговує на схвалення тих чи інших творчих здобутків або на беззаперечний осуд примітивізму бездарного «повторення». I тут потрібно висловити тільки жаль 3 приводу того, що у вітчизняному літературознавстві все ще немає ні чіткої системи критеріїв оцінок творів такого типу, ні такої ж чіткої їх класифікації. 
В російському літературознавстві вже є спроби диференціювати і процес, і наслідки рімейкування.

Так, у статті «Римейк в современной русской драматургии» О. Таразевич визначено п'ять «способів» саме рімейкових переробок класичних творів драматургії: рімейк-сіквел, рімейк-контамінація, рімейк-стьоб, рімейк-репродукція, рімейк-мотив. Сутність рімейка-сіквела полягає в тому, що автор обов' язково продовжує сюжет твору-оригіналу не тільки шляхом домислювання долі наявних персонажів, а й уведенням у твір-переробку нових дійових осіб. Рімейк-стьоб - це таке повноцінне повторення, під час здійснення якого драматург-рімейкер може повністю переконструювати й окремі сюжетні лінії, фабулу і весь сюжет, й окремі конфлікти чи систему конфліктів твору-оригіналу з різними цілями: або з метою розважити читача, або з ціллю переосмислити застарілі, на його думку, проблеми та ідеї по-новому, або ще з якимись іншими намірами.

На думку О. Таразевич, найбільш оригінальним $є$ рімейкконстатація, оскільки саме цей спосіб дозволяє авторові-рімейкеру поєднувати в одній «переробці» сюжети кількох класичних творів. До вказаних п'яти способів рімейкування додаються ще й такі «другорядні»: технологічний рімейк, рімейк-переказ, рімейк-модернізація, перекладний рімейк, рімейк-інтерпретація.

Так, при «технологічному» рімейкуванні зберігаються місце дії, основні дійові особи, тема, жанр твору, композиція. Рімейк-переказ будується обов'язково на основі сюжету якого-небудь міфу, легенди, саги, балади, думи тощо. Повною типологічною протилежністю виступає рімейк-інтерпретація, в основу якого частіше всього кладеться якась історична чи політична драма, і в ній здійснюється обов'язкове переосмислення причин, умов, мотивів мислення й мовлення дійових осіб.

Останнім часом усе більше стають популярними рімейки перекладного характеру, оскільки у творах цього типу передбачається не просте перекладання тексту, а й активна адаптація ментальності 
та культури оригіналу твору до культури й ментальності народу, від імені якого виступає автор-рімейкер-перекладач. Звичайно, з усього багатства літературно-критичних, особливо історико-літературних i суто теоретичних надбань науки про художню літературу як вид мистецтва конче необхідно віднайти наукову концепцію рімейкування (як процесу, і як його наслідків) та поняття про нього. Оскільки драматургічна творчість А. Ф. Ф. фон Коцебу мала досить оригінальний вплив на українську драматургію першої половини XIX ст. в Галичині. Так, на думку М. Возняка, під впливом «коцебщини» перебували Р. Мох, І. Озаркевич, І. Вітошинський. Відома п’єса А. Коцебу «Der Kosak und Freywillige. (Ein Liederspiel in einem Anfzuge)» зазнала багатьох українських переробок у Галичині.

Августо Коцебу будучи автором 73-х комедій, 60-ти драм і 15-ти трагедій, які мали досить умовне «відношення до справжнього мистецтва», то для нього «написання n'єс було чистим механічним прочесом» [Історія української літературної критики 1996: 93]. До того ж, цей драматург відверто заперечував існування опери як явища ненатурального, п’єси його справді потребували значних переробок. Більше того, як твердив Гофман, Августо Коцебу був майже зовсім позбавлений «справжнього поетичного духу» [Аникст 1980: 93]. Та при наявності браку репертуару українські аматорські театри були змушені удосконалювати і другорядні п’єси, у тому числі й твори Августо Коцебу, прилаштовуючи їх до умов тодішньої української театральної сцени.

Як твердить Н. Чечель, деякі здобутки українського сценічного мистецтва «традииійно розглядаються як непрофесійні, спонтанно-спорадичні та вторинно-аматорські мистецькі спроби», оскільки «критерій професійності такого типу творів був на той час відносний», бо в тодішній «украӥнській драматургії діяв принuуип тяглості й органічності розвитку» [Чечель 2004: 222]. I хоча 3 таким висновком повністю погодитися не можна, одначе слід усетаки визнати: західноукраїнські драматурги-аматори перших десятиріч XIX ст. справді особливо не переймалися тим, що їм рекомен- 
дувала літературна критика, яка все ще або подавала їм «відповідні зразки», або «з'ясовувала ступінь відповідності конкретних творів канонізованим нормам художньої форми і естетичного смаку», або «nіддавала суто формальному регламентуванню й оцінюванню» відповідно до ще досить «стійких канонів стилю, поетичних засобів мови автора й мовлення дійових осіб» [Чечель 2004: 6]. Та далеко не всі ці «поради», «настанови» доходили до творців таких п’єс.

Одним із перших рімейкованих перекладів творів А. Коцебу стала «Згублена дитина». Цю переробку здійснив письменник і громадський діяч, депутат галицького крайового сейму Василь Ковальський. Оскільки рімейк може бути і примітивним, і по-різному функціонально, формально та якісно довантаженим переказом - аж настільки, що сама «переробка» починає дійсно конкурувати 3 першоджерелом, то сам процес рімейкування і його наслідки та поняття про них вимушують нас говорити про той чи той рімейк по-різному: або як про самостійний і якоюсь мірою оригінальний художній твір, або як про таку «переробку», яка заслуговує чи на повне ії схвалення, чи на беззаперечний осуд примітивного й бездарного «повторення». I тут потрібно висловити тільки жаль 3 приводу того, що у вітчизняному літературознавстві все ще немає ні чіткої системи критеріїв оцінок творів такого типу, ні такої ж чіткої їх класифікації.

Назву п'єси В. Ковальський не змінив, а лише вказав, що це драма «въ I подъль (акть) зъ нтьецкого» [Возняк 1909: 53], але імена та прізвища дійових осіб суттєво адаптував для кращого сприймання українським реципієнтом: «Грябе Музе (староста), Михайло, єго старий слуга, Иванъ, хлопь, Олена, єго жӧнка, Дмитрунь, ихъ синъ, хлопецьь 6 до 8 льтьъ мающйи» [Возняк 1909: 53]. Проте в представленні дійової особи «жёнка» автор скористався прийомом білінгвістичного письма - він використав навіть деякі літери німецького алфавіту.

Місце дії перекладач-рімейкер максимально адаптував до місцевості, у якій він сам проживав: «Зрелище представляє поло- 
нину въ льсьь великомъ, зъ далека чути шумъ великой ргки» [Возняк 1909: 53].

Ява перша починається з монологу Грабе Музе, який за формою $є$ монологом-зізнанням старости Грабе Музе і густо пересипаний діалектизмами та вказівками на ті чи інші історичні події, котрі так чи інакше пов'язані з Галичиною - насамперед 3 діяльністю опришків.

3 монологу Грабе Музе стає відомо, що він хоче закінчити життя самогубством, проте причини такого прагнення в монолозі він не розкриває. I тільки з діалогу наступної, другої, яви стає відомо, що староста не може пережити смерть одного з його улюблених синів. А в розлогому діалозі Грабе Музе з його слугою Михайлом розкриваються справжні причини туги батька - багатослівні й переконливі репліки-інохарактеристики Михайла формують чіткі уявлення реципієнта про непрості стосунки батька з покійним сином: «Син, котрий Вам лише журу и гризоту все робивъ» [Возняк 1909: 55]; він приносив батькові чимало страждань, але Грабе Музе постійно сподівався, що його дитина «може поправивъ?» [Возняк 1909: 55]. Та коли слуга Михайло нагадав Грабе про ще одного сина Івана, якого той п’ять років тому вигнав із дому тільки за те, що хлопець покохав дівчину простого роду, батько був змушений не лише подумати про живого сина, а й покаятися в тому, що він «невинного и доброго сина дармо въ свъть друливъ, аби всг свои достатки другому роспутнику і невдячному дати. Скараний Отецьь! Кающйи ся Отещьь! котрїи межи гробами своихъ синовъ стоитъ...» [Возняк 1909: 57].

У яві третій діалог між Грабе Музе та шестилітнім хлопчиком Дмитром, якого той знайшов у своєму лісі, має інформативний характер: голодний самотній хлопчик декілька разів благає старого старосту дати щось поїсти, проте той категорично відмовляється пригостити хлопчика. I тільки тоді, коли дитина апелює до звичаїв і совісті Грабе («А мама мені казала, аби людей старих я шанував, бо воні добрі» [Возняк 1909:59]), він, розчулений, вирішив пригос- 
тити хлопчика, а потім і відвести до батьків. Дитяча щирість та безпосередність не тільки розчулили серце Грабе Музе, а й викликали в ньому співчуття до тих батьків, які шукають свого «згубленого сина». Репілки діалогу між Грабе і Дмитриком короткі, переважно окличного типу, але більшість із них не супроводжуються такими ремарками, котрі свідчать про невправність перекладача-ремейкера, хоча саме ці ремарки перетворилися на додатковий голос драматурга вони стали необхідними вказівками режисерові-постановнику й акторам, бо вони допомагають їм передати задуми автора.

У наступних явах п’єси події розвиваються уже в родині сина Грабе Івана та його дружини Олени. Подружжя болюче переживає зникнення сина Дмитрика. Батьки декілька діб шукали хлопчика, проте ніякої звістки про нього не отримали.

Знайшовши матір Дмитрика, Грабе не забарився їй запропонувати: «дайте мені хлопия, виховаю го і ущзасливію» [Возняк 1909 :62]. Проте така пропозиція викликала в Олени лише обурення: «Чи є який маєток въ свътьь, за котрий правдива мати може свою дитину дати?» [Возняк 1909: 62]. Зрозумівши те, що жінка не погодиться ні наякі умовляння, Грабе вирішив поговорити 3 батьком хлопчика.

Зустріч із батьком Дмитрика стала для старого Грабе зустріччю $з$ тим його сином Іваном, котрого він п'ять років тому вигнав 3 хати. Останній діалог п'єси свідчить про те, що батько із сином порозумілися, а в родині Грабе запанували спокій і радість.

Отже, перекладач-рімейкер Василь Ковальський намагався максимально адаптувати текст до сприймання його українським глядачем, але, на жаль, його переклад-рімейк виявився помітно спрощеним і слабким як з точки зору мікропоетики, так і $з$ точки зору макропоетики.

Та з огляду на те, що й обрана для переробки п’єса Августо Коцебу сама по собі була твором другорядним, автор-рімейкер все-таки зумів ії досить вдало адаптувати для тогочасного західноукраїнського аматорського театру. Саме тому «Згублена дитина» в 
переробці В. Ковальського багато разів ставилась місцевими аматорськими трупами, хоча досить швидко втратила актуальність і популярність, оскільки вона також мала низьку художню цінність виявилась не стільки перекладом-рімейком «Згубленої дитини», скільки більш-менш творчим переказом, наповненим функціонально визначеною діалектною лексикою та вказівками на деякі історичні події, котрі наблизили твір А. Коцебу до тогочасного українського глядача.

\section{БІБЛІОГРАФІЯ}

Аникст 1980 - Аникст А. Теория драмы на Западе в первой половине XIX века. Эпоха романтизма / Александр Аникст. - М. : Наука, 1980. - 343 с.

Возняк 1909 - Возняк М. Українські драматичні вистави в Галичині в першій половині XIX століття / Михайло Возняк. - Львів : Друкарня Наукового товариства ім. Т. Шевченка, 1909. - 63 с.

Історія української літературної критики 1996 - Історія української літературної критики та літературознавства : хрестоматія : у 3 кн. / упоряд.

П. М. Федченко, М. М. Павлюк, Т. В. Бовсунівська ; за ред. П. М. Федченка. Кн. 1. - К. : Либідь, 1996. - 416 с.

Коцебу 1873 - Коцебу А. Ф. Ф. фон (Записки о Ф. О. Туманском) / Августо Коцебу // Русская старина. - 1873. - Т. 8. - Кн. 10. - С. 589-593.

Москаленко 2006 - Москаленко М. Нариси з історії українського перекладу / Михайло Москаленко // Всесвіт. - 2006.

Чечель 2004 - Чечель Н. Повертаючи стиль : Філософсько-антропологічний дискурс української видовищної і драматичної культури від початків до XVIII ст. : монографія / Наталя Чечель. - К. : Видавець ПАРАПАН, 2004. - 240 с. 